\title{
Extensive intracranial calcifications in a patient with a novel polymerase gamma-1 mutation
}

Figure 1 CT head demonstrates profound cerebellar and pontine calcifications, less so in the globus pallidus

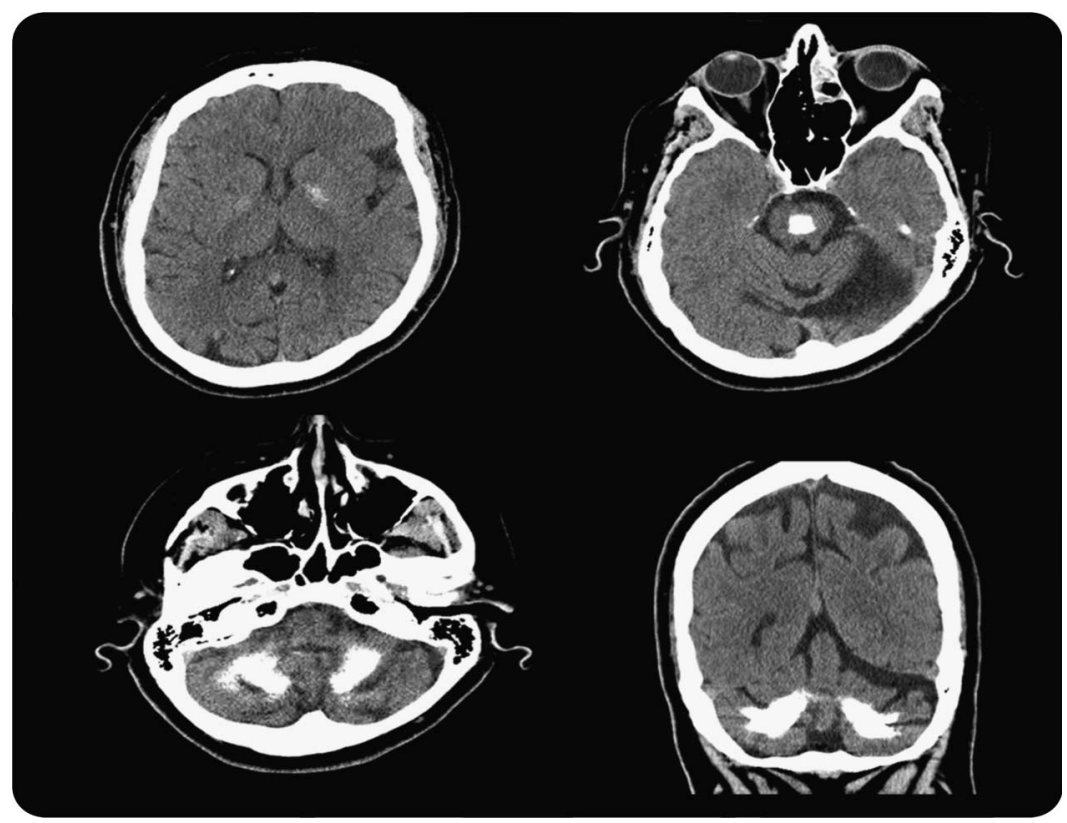

A 55-year-old woman presented to our center with an almost lifelong action tremor, associated with peripheral neuropathy, progressive sensorineural hearing loss, and a strong family history of tremor. CT of the brain was notable for extensive intracranial calcifications, much more prominent in the dentate nucleus, cerebellar hemispheres, and midpons, compared to the globus pallidus (figure 1). T1-weighted MRI demonstrated hypointense signal in the aforementioned areas (figure 2). Polymerase gamma-1 (POLG1) gene analysis revealed a novel heterozygous sequence variant at c3239G > c; p.Ser1080Thr. Similar diffuse intracranial calcification can be seen in a variety of disorders including idiopathic basal ganglia calcifications and spinocerebellar ataxia $20 .{ }^{1}$ Mitochondrial disorders ${ }^{2}$ are a well-recognized cause; however, to our knowledge this is the first time that such extensive intracranial calcium deposits have been described in a patient with a POLG1 mutation.

Figure 2 T1-weighted MRI brain shows hypointense signal in the globus pallidus and midpons

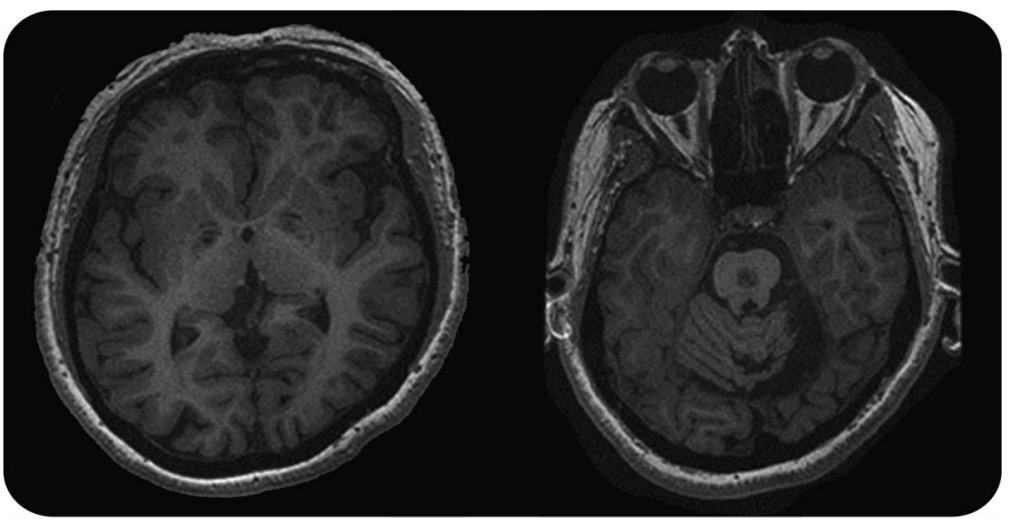


From the Morton and Gloria Shulman Movement Disorders Clinic and the Edmond J. Safra Program in Parkinson's Disease (C.S., E.M., A.E.L.), Toronto Western Hospital, Toronto, Canada; Parkinson's Disease and Movement Disorders Program (C.S.), Henry Ford Hospital, West Bloomfield, MI; and Department of Psychiatry and Neurology, Movement Disorders Unit (E.M.), University Hospital Center (CHU) of Grenoble, Grenoble, France.

Author contributions: Dr. Sidiropoulos: study concept and design. Dr. Sidiropoulos: acquisition of data. Drs. Sidiropoulos, Moro, Lang: analysis and interpretation of data. Drs. Moro, Lang: critical revision of the manuscript for important intellectual content. Drs. Moro, Lang: study supervision.

Study funding. No targeted funding reported.

Disclosure: C. Sidiropoulos reports no disclosures. E. Moro has received honoraria from Medtronic for consulting services and lecturing and has received research support from St. Jude Medical, CurePSP, CIHR, and educational grant support from Medtronic. A. Lang has served as an advisor for Abbott, Allon Therapeutics, Astra Zeneca, Avanir Pharmaceuticals, Biogen Idec, Biovail, Boehringer-Ingelheim, Cephalon, Ceregene, Eisai, GSK, Lundbeck A/S, Medtronic, Merck Serono, Merke, Novartis, and Teva; received grants from Canadian Institutes of Health Research, Dystonia Medical Research Foundation, Michael J. Fox Foundation, National Parkinson Foundation, Parkinson Society of Canada, and Ontario Problem Gambling Research Center; and has served as an expert witness in cases related to the welding industry. Go to Neurology.org for full disclosures.

Correspondence to Dr. Sidiropoulos: csidiro1@hfhs.org

1. Knight MA, Gardner RJ, Bahlo M, et al. Dominantly inherited ataxia and dysphonia with dentate calcification: spinocerebellar ataxia type 20. Brain 2004;127:1172-1181.

2. Finsterer J. Central nervous system imaging in mitochondrial disorders. Can J Neurol Sci 2009;36:143-153.

\section{NeuroImages Are Free at www.neurology.org!}

All Neurology ${ }^{\circledR}$ NeuroImages can now be freely accessed on the Neurology Web site. See them at www.neurology.org, where you can also sign up for journal email alerts and check out other online features, including the Resident \& Fellow section, Neurology: Clinical Practice, and the weekly Neurology Podcasts. 


\section{Neurology}

\section{Extensive intracranial calcifications in a patient with a novel polymerase gamma-1 mutation}

Christos Sidiropoulos, Elena Moro and Anthony E. Lang

Neurology 2013;81;197-198

DOI 10.1212/WNL.0b013e31829a3438

\section{This information is current as of July 8, 2013}

\section{Updated Information \& Services}

References

Subspecialty Collections

Permissions \& Licensing

Reprints including high resolution figures, can be found at: http://n.neurology.org/content/81/2/197.full

This article cites 2 articles, 0 of which you can access for free at: http://n.neurology.org/content/81/2/197.full\#ref-list-1

This article, along with others on similar topics, appears in the following collection(s):

All Movement Disorders

http://n.neurology.org/cgi/collection/all_movement_disorders Basal ganglia

http://n.neurology.org/cgi/collection/basal_ganglia

Tremor

http://n.neurology.org/cgi/collection/tremor

Information about reproducing this article in parts (figures,tables) or in its entirety can be found online at:

http://www.neurology.org/about/about_the_journal\#permissions

Information about ordering reprints can be found online:

http://n.neurology.org/subscribers/advertise

Neurology $®$ is the official journal of the American Academy of Neurology. Published continuously since 1951, it is now a weekly with 48 issues per year. Copyright (O) 2013 American Academy of Neurology. All rights reserved. Print ISSN: 0028-3878. Online ISSN: 1526-632X.

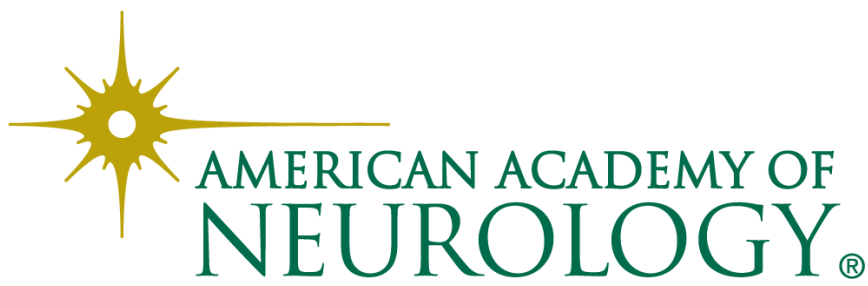

